\title{
Growth of the Sayram Lake and retreat of its water-supplying glaciers in the Tianshan Mountains from 1972 to 2011
}

\author{
CHENG Weiming ${ }^{1 *}$, WANG Nan ${ }^{1,2}$, ZHAO Shangmin ${ }^{3}$, FANG Yue ${ }^{1,2,4}$, ZHAO Min ${ }^{1,2}$ \\ ${ }^{1}$ State Key Laboratory of Resources and Environmental Information System, Institute of Geographic Sciences and Natural \\ Resources Research, Chinese Academy of Sciences, Beijing 100101, China; \\ ${ }^{2}$ University of Chinese Academy of Sciences, Beijing 100049, China; \\ ${ }^{3}$ Department of Surveying and Mapping, College of Mining Engineering, Taiyuan University of Technology, Taiyuan 030024, \\ China; \\ ${ }^{4}$ Xinjiang Institute of Ecology and Geography, Chinese Academy of Sciences, Urumqi 830011, China
}

\begin{abstract}
Inland lakes and alpine glaciers are important constituents of water resources in arid and semiarid regions. Understanding their variations is critical for both an accurate evaluation of the dynamic changes of water resources and the retrieval of climatic information. On the basis of earlier researches, this study investigated the growth of the Sayram Lake and the retreat of its water-supplying glaciers in the Tianshan Mountains using long-term sequenced remote sensing images. Our results show that over the past 40 years, the surface area and the water level of the lake has increased by $12.0 \pm 0.3 \mathrm{~km}^{2}$ and $2.8 \mathrm{~m}$, respectively, and the area of its water-supplying glaciers has decreased continuously since the early 1970s with a total reduction of about $-2.13 \pm 0.03 \mathrm{~km}^{2}$. Our study has indicative significance to the research of regional climate change.
\end{abstract}

Keywords: Sayram Lake; inland lake; areal variation; water level change; glacial retreat

Citation: CHENG Weiming, WANG Nan, ZHAO Shangmin, FANG Yue, ZHAO Min. 2016. Growth of the Sayram Lake and retreat of its water-supplying glaciers in the Tianshan Mountains from 1972 to 2011. Journal of Arid Land, 8(1): 13-22. doi: 10.1007/s40333-015-0139-4

The lakes in alpine mountains generally remain in a natural state due to sparse population distribution and few human activities. Therefore, their variations of water level are regarded as sensitive indicators to regional climate change (Guo et al., 2003; Ding et al., 2006; Hu et al., 2007), especially in arid and semiarid regions (Fan and Li, 1984; Qin, 1999). Usually, lake evolution research involves many factors, including natural and anthropogenic ones, among which regional climate change is significantly involved (Shi and Zhang, 1995), because the water cycle in a drainage basin is related to rainfall, evaporation, and the meltwater of glaciers and snow (Ma et al., 2003). This is why it is necessary to study the recent changes of the lakes in alpine mountains.

Changes of alpine mountain glaciers are another optimal natural indicator of climatic change. The Tianshan Mountain area within China has 7,934 glaciers, and is one of the main distribution areas of alpine mountain glaciers in the world (Liu et al., 2015). Many scientists have analyzed the relationship between climate change and glacier retreat, based on topographic and remote sensing data (Aizen et al., 2007; Kutuzov and Shahgedanova, 2009; Wang et al., 2011). It has

*Corresponding author: CHENG Weiming (E-mail: chengwm@lreis.ac.cn)

Received 2014-11-17; revised 2015-05-04; accepted 2015-07-01

(C) Xinjiang Institute of Ecology and Geography, Chinese Academy of Sciences, Science Press and Springer-Verlag Berlin Heidelberg 2016 
been established that the retreat of alpine mountain glaciers was serious over the last 40 years (Bolch, 2007; Kong and Pang, 2012). The same trends have been observed on the Tibetan Plateau of China (Bolch et al., 2010; Yao et al., 2012) and in Central Asia (Sorg et al., 2012), which indicates that glacier shrinkage is most pronounced in middle latitude regions with high elevations and sparse population distribution.

A clear understanding of the variation of inland lakes and glacial retreat, in response to climate change, is critical for an accurate evaluation of water resources and a retrieval of climate information. More and more studies (Fan and Li, 1984; Hu et al., 2002; Gao and Jia, 2005; Ding et al., 2006; Bai et al., 2011; Li et al., 2011; Kropáček et al., 2012) have indicated that the surface areas of numerous inland lakes in arid and semiarid regions have decreased considerably since 1950. The water levels of most lakes in the basin regions of China's Qinghai province (Gao and Jia, 2005), Australia (Jones et al., 2001), Africa (Mercier et al., 2002), and North Dakota of North America (Donald and Thomas, 1997), have declined because of the combined effects of drought, warming, and human activities. Moreover, many lakes (e.g. Ebinur Lake, Ayding Lake, and Lop Nur) in Xinjiang are shrinking and even drying up (Fan and Li, 1984; Qin, 1999; Bai et al., 2011). Conversely, the water levels in a small number of mountain lakes in Xinjiang (Gao and Jia, 2005; Ding et al., 2006; Hu et al., 2007; Bai et al., 2011) and on the Qinghai-Tibetan Plateau (Liu et al., 2009; Zhang et al., 2011; Li and Sheng, 2013; Yao et al., 2014) have risen in response to increased precipitation and glacial melt (Aizen et al., 1996, 2007; Kutuzov and Shahgedanova, 2009). All these studies have indicated that lakes could be affected at varying degrees by climate change.

The water level of the Sayram Lake in the Tianshan Mountains of China has increased slightly over the past 40 years, which has resulted in the steady growth of its areal extent (Wang, 1978; Fan and Li, 1984; Shi and Zhang, 1995; Guo et al., 2003; Ma et al., 2003; Gao and Jia, 2005; Ding et al., 2006; Bai et al., 2011). Chai et al. (2013) focused on the effects of climatic fluctuations on the changes of the Sayram Lake, based on long-term sequenced remote sensing images and meteorological data. A geographic information system (GIS) method was used to obtain the hypsometry of the Sayram Lake region, and several methods were proposed to estimate the water level change caused by evaporation from rising temperatures and increasing precipitation. The temperature and precipitation in the Sayram Lake region have risen with average increases of more than $1.8^{\circ} \mathrm{C}$ and $82 \mathrm{~mm}$, respectively, based on four meteorological stations (Wenquan, Alashankou, Jinghe, and Yining) near the Sayram Lake during the period of 1970-2009 (Chai et al., 2013). Variation of the water level in the lake has been consistent with local climatic changes, and the lake area exhibits linear relationships with local temperature and precipitation data. According to hypsometric data of the region, it is estimated that the water level of the lake has risen by $2.8 \mathrm{~m}$ and the water volume has increased by $12.9 \times 10^{8} \mathrm{~m}^{3}$ over the past 40 years. However, Chai et al. (2013) did not focus on the variations of alpine glaciers, and did not validate the applicability of the hypsometry method to the Sayram Lake region. Thus, based on the results of their research, this study extended the analysis of the variations of the Sayram Lake and the changes of alpine glaciers in the Sayram Lake region, quantitatively addressing the reasons for the variations and the significance of climate change. This study can accurately reflect local climate change because the Sayram Lake is a closed alpine lake little affected by human activities.

\section{Study area}

The Sayram Lake region was selected as the study area (Fig. 1). The lake is renowned as a "pearl" on the Silk Road and it is the largest alpine and cold-water inland lake in Xinjiang (Chai et al., 2013). Geologically, the Sayram Lake basin is a graben fault type, indicating that the Sayram Lake is a fracture lake (Wang, 1978). There are more than 20 small rivers supplied by alpine glaciers and snow melt in the Sayram Lake region, and about 10 small villages where the local people are engaged in animal grazing for a living, and there is no agriculture or industry (Chai et al., 2013). 

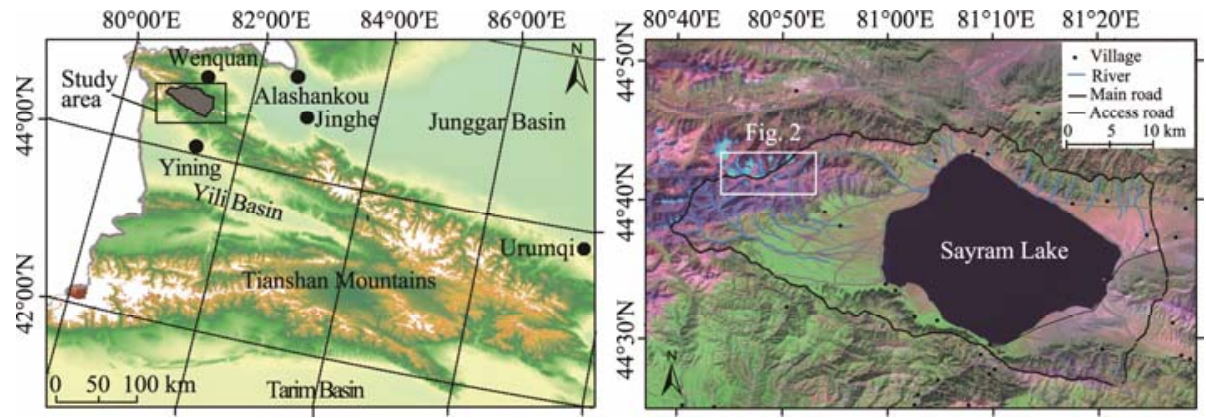

Fig. 1 Location of the study area in the Tianshan Mountains of Xinjiang. The white regions show glaciers distributed in Tianshan Mountains from the Chinese Glacier Inventory (after Chai et al., 2013). The right is from composite images of Landsat TM bands 7, 4, and 2, 24 Aug 2007.

There are 13 glaciers of various sizes (a total area of around $4.28 \mathrm{~km}^{2}$ ) among the northwestern mountain peaks in the region, and their outlines, taken from the Chinese Glacier Inventory, are shown in Fig. 2 (Lanzhou Institute of Glaciology and Cryopedology, Chinese Academy of Sciences, 1986).

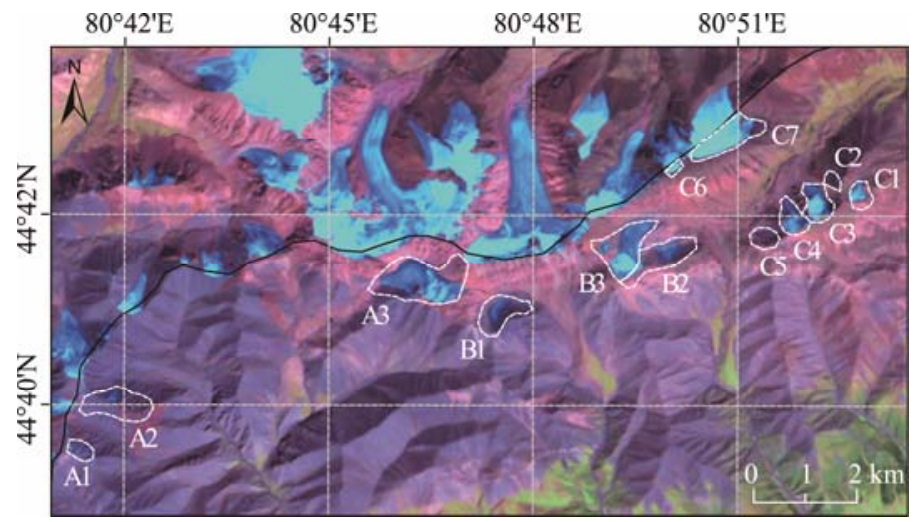

Fig. 2 Thirteen glaciers in the Sayram Lake watershed (composite images of Landsat TM bands 7, 4, and 2, 24 Aug 2007). Glacier designations: A1-5Y745A0001; A2-5Y745A0002; A3-5Y745A0003; B1-5Y745B0001; B2-5Y745B0002; B3-5Y745B0003; C1-5Y745C0001; C2-5Y745C0002; C3-5Y745C0003; C4-5Y745C0004; C5-5Y745C0005; C6-5Y745C0006; C7-5Y745C0007.

\section{Data and methods}

\subsection{Data acquisition}

\subsubsection{Landsat remote sensing data}

Based on cloud percentage and acquisition date (http://glovis.usgs.gov), we chose representative images in different years (1972, 1975-1978, 1990, and 1998-2011) (Table 1). Long-term sequenced Landsat Multispectral Scanner (MSS) and Thematic Mapper (TM)/Enhanced Thematic Mapper (ETM) images were used as the data sources. Prior to the analysis, they were geometrically rectified, radiometrically corrected, and stored in GeoTiff format in single bands. The resolutions of Landsat MSS and Landsat TM/ETM imageries are 90 and $30 \mathrm{~m}$, respectively (Table 1). These remote sensing images were used to extract glacier information in 1975, 1977, 1990, 2002, 2007, and 2011, respectively.

\subsubsection{ICESat data}

All Ice, Cloud, and land Elevation Satellite (ICESat)/Geoscience Laser Altimeter (GLA14) Release-31 elevation data for the study area during 2003-2008 were obtained from the U.S. National Snow and Ice Data Center (Table 2). GLA System elevations are referenced using the 
Topex/Poseidon ellipsoid and EGM96 geoid. ICESat/GLA14 data have high vertical accuracy: about $0.1 \mathrm{~m}(1 \sigma)$ for flat bare locations and $1 \mathrm{~m}(1 \sigma)$ for undulating vegetated surfaces (González et al., 2010). The attained accuracy can reach $0.1 \mathrm{~m}$ for monitoring lake elevation in this study.

Table 1 Information on the remote sensing images

\begin{tabular}{cccc}
\hline & Landsat MSS & Landsat TM & Landsat ETM \\
\hline \multirow{3}{*}{ Acquisition date } & 22 Sep 1972; 8 Nov & 27 Aug 1990; 2 Oct 1998; 21 & 26 Aug 1999; 28 Aug 2000; 14 Jul \\
& 1975; 16 Oct 1976; 25 & Aug 2006; 24 Aug 2007; 30 Sep & 2001; 18 Aug 2002; 20 Jul 2003; 24 \\
& Jun 1977; 13 Aug 1978 & 2009; 3 Oct 2010; 19 Aug 2011 & Sep 2004; 27 Sep 2005; 15 Jun 2008 \\
Resolution (m) & 90 & 30 & 30 \\
\hline
\end{tabular}

\subsubsection{SRTM data}

Another principal dataset was the Shuttle Radar Topography Mission digital elevation model (SRTM-DEM, V4.1) (http://srtm.csi.cgiar.org), which has a horizontal resolution of approximately $90 \mathrm{~m}$. The designed vertical error is $16 \mathrm{~m}$; however, through global estimation, the vertical error is actually higher than $9 \mathrm{~m}$ (Farr et al., 2007). SRTM data was used for comparison of lake elevations and had a better understanding of landform differences in the regional area.

Table 2 Statistics showing 12 tracks with ICESat elevation data obtained from 2003-2008

\begin{tabular}{|c|c|c|c|c|c|}
\hline Date & $\begin{array}{l}\text { Maximum elevation } \\
(\mathrm{m})\end{array}$ & $\begin{array}{l}\text { Minimum elevation } \\
(\mathrm{m})\end{array}$ & $\begin{array}{l}\text { Mean elevation } \\
(\mathrm{m})\end{array}$ & $\begin{array}{c}\text { Number of } \\
\text { statistical points }\end{array}$ & $\begin{array}{c}\text { Number of sampling } \\
\text { points }\end{array}$ \\
\hline 24 Oct 2003 & $2,074.00$ & $2,073.54$ & $2,073.67$ & $8^{(\mathrm{a})}$ & 25 \\
\hline 25 Feb 2004 & $2,074.90$ & $2,073.35$ & $2,073.66$ & 22 & 22 \\
\hline 26 May 2004 & $2,073.99$ & $2,073.80$ & $2,073.89$ & 37 & 37 \\
\hline 12 Oct 2004 & $2,073.99$ & $2,072.53$ & $2,073.73$ & 57 & 57 \\
\hline 28 May 2005 & $2,074.02$ & $2,073.86$ & $2,073.92$ & 57 & 57 \\
\hline 29 Oct 2005 & $2,074.03$ & $2,073.87$ & $2,073.96$ & 57 & 57 \\
\hline 1 Jun 2006 & $2,073.89$ & $2,073.55$ & $2,073.79$ & 19 & 19 \\
\hline 2 Nov 2006 & $2,074.01$ & $2,073.46$ & $2,073.90$ & 53 & 53 \\
\hline 19 Mar 2007 & $2,073.98$ & $2,073.49$ & $2,073.91$ & 57 & 57 \\
\hline 10 Oct 2007 & $2,074.10$ & $2,073.95$ & $2,074.02$ & 57 & 57 \\
\hline 25 Feb 2008 & $2,074.12$ & $2,073.67$ & $2,074.00$ & 57 & 57 \\
\hline 12 Oct 2008 & $2,074.18$ & $2,073.30$ & $2,073.83$ & $34^{(\mathrm{b})}$ & 44 \\
\hline
\end{tabular}

Note: (a) 17 points whose elevations were more than 3,218 m were deleted; (b) 10 points whose elevations were more than $2,830 \mathrm{~m}$ were deleted.

\subsection{Methods}

\subsubsection{Glacier information extraction}

Dozier (1989) asserted that the Normalized Difference Snow Index (NDSI) could be used to distinguish snow, rocky soil, and cloud cover. It is effective for snow mapping in rough topography and can provide a sharp definition to the boundary between a glacier terminus and the surrounding moraine. Therefore, the NDSI method was applied to extract glacier and snow information based on remote sensing images. The NDSI can be determined using the digital numbers of two TM bands:

$$
\mathrm{NDSI}=\left(\mathrm{TM}_{\text {green }}-\mathrm{TM}_{\text {infrared }}\right) /\left(\mathrm{TM}_{\text {green }}+\mathrm{TM}_{\text {infrared }}\right) \text {. }
$$

Where $\mathrm{TM}_{\text {green }}$ represents the green band of $\mathrm{TM} / \mathrm{ETM}$ and $\mathrm{TM}_{\text {infrared }}$ is the shortwave infrared band of TM/ETM.

The NDSI method is not suitable for MSS data because of the lack of a shortwave infrared band. Artificial visual interpretation was used to extract glacier outlines from MSS data. The Glacial Inventory of China was adopted to estimate the accuracy of the extraction results (Shi, 2005). 
2.2.2 Comparison of lake elevations from ICESat footprints and the hypsometry method

We converted the ICESat elevations (ICESat_elevation_measured) to WGS84 ellipsoid elevations (ICESat_elevation) (Zhang et al., 2011) using Eq. 2, for comparison with the model-produced elevations.

ICESat_elevation=ICESat_elevation_measured-ICESat_geoid-0.7.

Where the ICESat_elevation_measured and ICESat_geoid were obtained directly from the ICESat data and the $0.7 \mathrm{~m}$ represents the offset from the Topex/Poseidon ellipsoid to the WGS84 ellipsoid (Zhang et al., 2011; Kropáček et al., 2012).

By intersecting the ICESat data of each satellite track with the Sayram Lake, we obtained 12 tracks with sufficient ICESat elevation data from 2003 to 2008. All footprints (elevations) were examined carefully to remove obvious outliers according to historical elevation records of the lake (Wang, 1978). Thus, reasonable ICESat elevation data were acquired for different time (Table 2).

\section{Results}

\subsection{Areal variation of the Sayram Lake determined from remote sensing data}

Areal variation, water level and volume of the Sayram Lake for the past 40 years, based on the calculation method of the Normalized Difference Water Index (McFeeters, 1996), are presented in Table 3 and Fig. 3. The surface area of the lake reached $465.2 \pm 0.2 \mathrm{~km}^{2}$ in 2011 , an increase of $12.0 \pm 0.3 \mathrm{~km}^{2}$ from $453.2 \pm 0.2 \mathrm{~km}^{2}$ in 1972 . The areal change was linear with a correlation coefficient $R^{2}$ of 0.99 . The annual increase of the lake area was small, i.e. less than $0.7 \mathrm{~km}^{2}$. The uncertainty of the lake area derived from remote sensing images was less than $0.8 \mathrm{~km}^{2}$, which suggested that these uncertainties have arisen from the approximate annual increase of the lake area.

Table 3 Areal change of the Sayram Lake and alpine glaciers over the past 40 years

\begin{tabular}{|c|c|c|c|c|c|}
\hline Year & $\begin{array}{l}\text { Lake water } \\
\text { surface area } \\
\quad\left(\mathrm{km}^{2}\right)\end{array}$ & $\begin{array}{c}\text { Lake area } \\
\text { changing rate } \\
\left(\mathrm{km}^{2} / \mathrm{a}\right)\end{array}$ & $\begin{array}{c}\text { Lake } \\
\text { water level } \\
(\mathrm{m})\end{array}$ & $\begin{array}{l}\text { Lake } \\
\text { water volume } \\
\left(\times 10^{8} \mathrm{~m}^{3}\right)\end{array}$ & $\begin{array}{l}\text { Glacier area } \\
\quad\left(\mathrm{km}^{2}\right)\end{array}$ \\
\hline 1972 & $453.2 \pm 0.2$ & - & $2,071.6$ & 202.6 & $*$ \\
\hline 1975 & $453.9 \pm 0.4$ & 0.2 & $2,071.7$ & 203.1 & $4.55 \pm 0.03$ \\
\hline 1976 & $454.5 \pm 0.5$ & 0.6 & $2,071.8$ & 203.5 & * \\
\hline 1977 & $455.1 \pm 0.6$ & 0.6 & $2,071.9$ & 204.0 & $4.28 \pm 0.02$ \\
\hline 1978 & $455.5 \pm 0.5$ & 0.4 & $2,072.0$ & 204.4 & $*$ \\
\hline 1990 & $459.2 \pm 0.2$ & 0.3 & $2,072.3$ & 205.8 & $3.67 \pm 0.03$ \\
\hline 1998 & $460.8 \pm 0.2$ & 0.2 & $2,072.8$ & 208.1 & * \\
\hline 1999 & $461.1 \pm 0.4$ & 0.3 & $2,072.9$ & 208.6 & $3.34 \pm 0.04$ \\
\hline 2000 & $461.7 \pm 0.7$ & 0.6 & $2,073.0$ & 209.0 & $*$ \\
\hline 2001 & $462.2 \pm 0.2$ & 0.5 & $2,073.2$ & 209.9 & $*$ \\
\hline 2002 & $462.4 \pm 0.6$ & 0.2 & $2,073.3$ & 210.4 & $2.97 \pm 0.03$ \\
\hline 2003 & $462.7 \pm 0.3$ & 0.3 & $2,073.4$ & 210.9 & $*$ \\
\hline 2004 & $462.9 \pm 0.1$ & 0.2 & $2,073.5$ & 211.3 & $*$ \\
\hline 2005 & $463.2 \pm 0.2$ & 0.3 & $2,073.6$ & 211.8 & $*$ \\
\hline 2006 & $463.4 \pm 0.6$ & 0.2 & $2,073.7$ & 212.3 & $*$ \\
\hline 2007 & $463.6 \pm 0.4$ & 0.2 & $2,073.8$ & 212.7 & $2.63 \pm 0.02$ \\
\hline 2008 & $463.9 \pm 0.1$ & 0.3 & $2,073.9$ & 213.2 & $*$ \\
\hline 2009 & $464.3 \pm 0.3$ & 0.4 & $2,074.0$ & 213.7 & $*$ \\
\hline 2010 & $464.8 \pm 0.2$ & 0.5 & $2,074.2$ & 214.6 & $*$ \\
\hline 2011 & $465.2 \pm 0.2$ & 0.4 & $2,074.4$ & 215.5 & $2.42 \pm 0.02$ \\
\hline $\begin{array}{c}\text { Increasing/decreasing } \\
\text { amount }\end{array}$ & $12.0 \pm 0.3$ & & 2.8 & 12.9 & $-2.13 \pm 0.03$ \\
\hline
\end{tabular}

Note: * designates snow or cloud cover in remote sensing images (for high mountain glaciers). 
The continuous rise of the lake water level led to the flooding of an old national road and an access road in the Sayram Lake region, which resulted in reconstruction at a high elevation. In addition, lake islands, formerly connected by bridges that allowed access by foot, became separated by water and accessible only by boat (Chai et al., 2013).

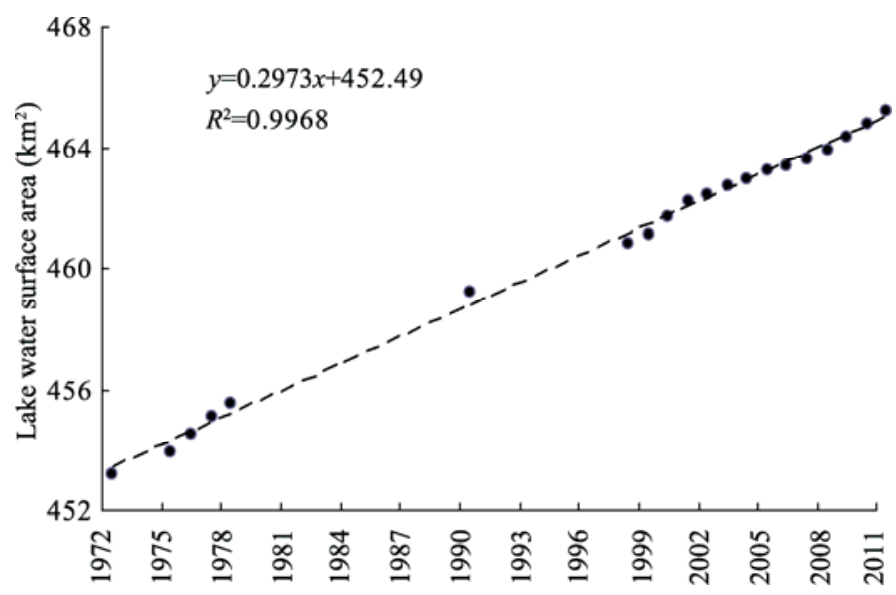

Fig. 3 Areal variation of the Sayram Lake based on remote sensing images over the past 40 years

\subsection{Water level change of the Sayram Lake extracted from remote sensing data}

The water level change of the Sayram Lake over the past 40 years is shown in Fig. 4 . The water level has increased by $2.8 \mathrm{~m}$ during the period of 1972-2011. The water level change is approximately linear, with a correlation coefficient $R^{2}$ of 0.947 . During the $1970 \mathrm{~s}$, the water level increased by $0.4 \mathrm{~m}$, and from 1978 to 1990, increased slowly. By 1990, the water level has reached 2,072 m. From 2000 onwards, the lake water level came into a steady increasing stage. In the last 10 years, the water level increased by $1.4 \mathrm{~m}$.

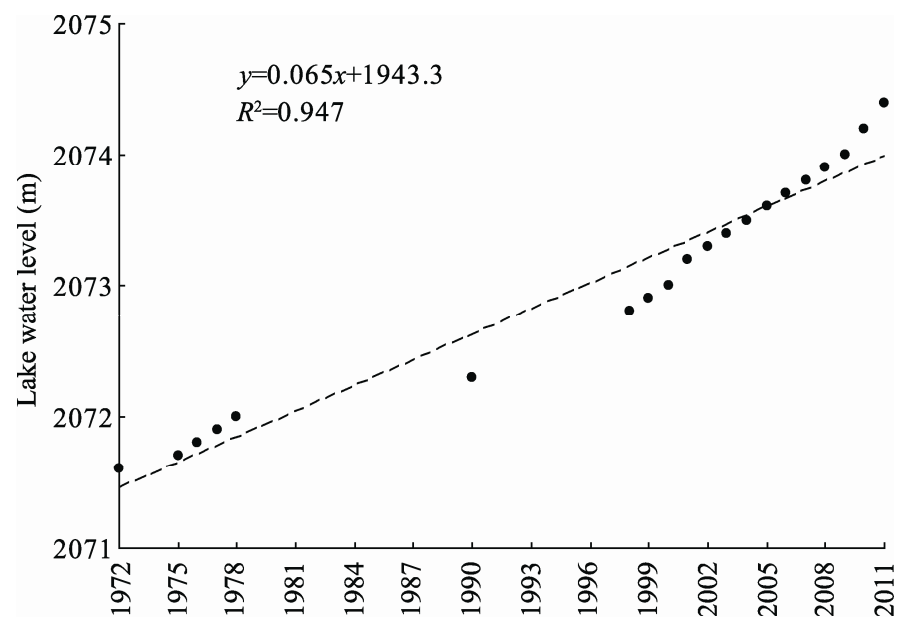

Fig. 4 Water level variation of the Sayram Lake based on remote sensing images over the past 40 years

\subsection{Glacial retreat based on remote sensing data}

Areal values of glaciers in the high alpine mountains for the past 40 years, based on Eq. 1, are listed in Table 3. The glacial area has decreased continuously from $4.55 \pm 0.03 \mathrm{~km}^{2}$ in 1975 to $2.42 \pm 0.04 \mathrm{~km}^{2}$ in 2011 , a decline of about $2.13 \pm 0.03 \mathrm{~km}^{2}$. Overall, the trend of areal retreat is linear with an $R^{2}$ value of 0.99 (Fig. 5). 


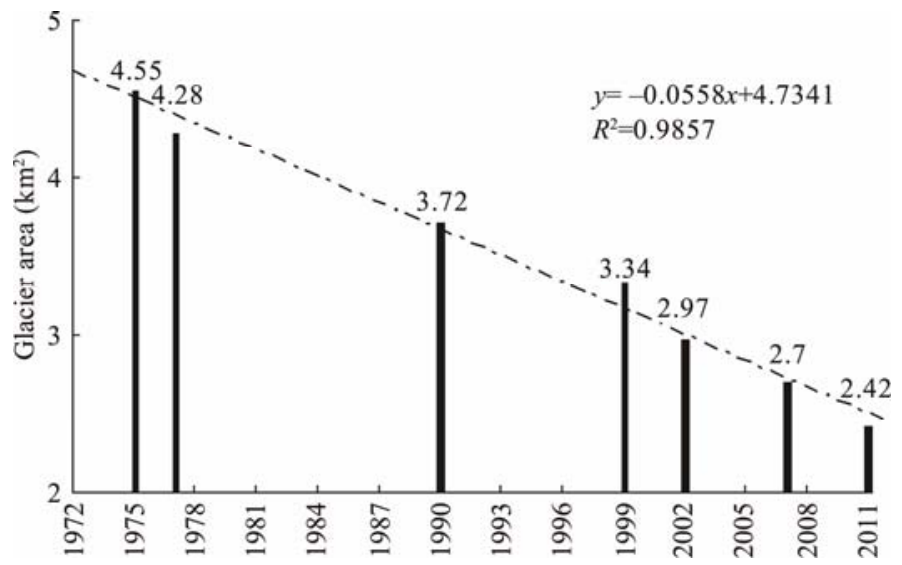

Fig. 5 Areal variation of alpine glaciers over the past 40 years

Table 4 compares the area of 13 glaciers in the Chinese Glacier Inventory over the past 40 years. All the glaciers are shown to be retreating and the smaller glaciers are retreating the most quickly. For example, four glaciers (5Y745A0001, Y745C0002, 5Y745C0005, and 5Y745C0006) have virtually disappeared (Shi, 2005).

Table 4 Decrease of 13 glaciers in the Chinese Glacier Inventory over the past 40 years

\begin{tabular}{|c|c|c|c|}
\hline \multirow{2}{*}{ No. of glaciers } & Area in 1975 & Area in 1990 & Area in 2007 \\
\hline & \multicolumn{3}{|c|}{$\left(\mathrm{km}^{2}\right)$} \\
\hline $5 Y 745 \mathrm{~A} 0001$ & 0.27 & 0.13 & 0.01 \\
\hline $5 \mathrm{Y} 745 \mathrm{~A} 0002$ & 0.44 & 0.26 & 0.04 \\
\hline $5 Y 745 A 0003$ & 1.07 & 0.85 & 0.78 \\
\hline $5 Y 745 B 0001$ & 0.27 & 0.24 & 0.15 \\
\hline $5 Y 745 B 0002$ & 0.28 & 0.25 & 0.11 \\
\hline $5 Y 745 B 0003$ & 0.87 & 0.81 & 0.58 \\
\hline $5 \mathrm{Y} 745 \mathrm{C} 0001$ & 0.17 & 0.13 & 0.07 \\
\hline $5 \mathrm{Y} 745 \mathrm{C} 0002$ & 0.02 & 0.01 & 0.01 \\
\hline $5 Y 745 \mathrm{C} 0003$ & 0.25 & 0.21 & 0.20 \\
\hline $5 Y 745 \mathrm{C} 0004$ & 0.20 & 0.17 & 0.15 \\
\hline $5 Y 745 \mathrm{C} 0005$ & 0.03 & 0.02 & 0.01 \\
\hline $5 Y 745 \mathrm{C} 0006$ & 0.09 & 0.07 & 0.05 \\
\hline $5 Y 745 \mathrm{C} 0007$ & 0.59 & 0.57 & 0.54 \\
\hline Total & 4.55 & 3.72 & 2.70 \\
\hline
\end{tabular}

\section{Discussion}

\subsection{Comparison of elevations from the hypsometry method and ICESat data}

The mean elevation of the Sayram Lake from 2003-2008 by ICESat was 2,073.85 m, very close to the mean lake elevation of $2,073.65 \mathrm{~m}$ calculated using the hypsometry method over the same period, with a slight difference of $0.20 \mathrm{~m}$ (Table 5). Mean ICESat elevations show a linearly rising trend, as do the hypsometric elevations, although the former are slightly higher than the latter (Table 5).

Most of the 12 tracks used for determining ICESat elevations in this study were captured in winter, i.e. from October to March (Table 2). During this season, the lake water was frozen and the frozen lake surface was covered by snow, which elevated the height of the lake surface slightly. 
Table 5 Elevations of the Sayram Lake from ICESat footprints and the hypsometry method

\begin{tabular}{cccc}
\hline Year & $\begin{array}{c}\text { Mean elevation from ICESat footprints } \\
(\mathrm{m})\end{array}$ & $\begin{array}{c}\text { Elevation from the hypsometry method } \\
(\mathrm{m})\end{array}$ & Difference \\
\hline 2003 & $2,073.67$ & $2,073.4$ & 0.27 \\
2004 & $2,073.76$ & $2,073.5$ & 0.26 \\
2005 & $2,073.94$ & $2,073.6$ & 0.34 \\
2006 & $2,073.84$ & $2,073.7$ & 0.14 \\
2007 & $2,073.97$ & $2,073.8$ & 0.17 \\
2008 & $2,073.91$ & $2,073.9$ & 0.01 \\
Mean & $2,073.85$ & $2,073.65$ & 0.20 \\
\hline
\end{tabular}

\subsection{Comparison of lake water level changes with other regions}

Geologically, the Sayram Lake basin is a graben fault basin in the Tianshan Mountains, and there are many alpine lakes with similar tectogenesis in the high mountains in China, such as the Har Lake in the Qilian Mountains, the Palgon Lake in the Karakoram Mountains, and the Nam Lake on the Changtang Plateau. These alpine mountain lakes have approximately similar water-supplying conditions and independent catchment basin environment, and the main consumption of water is via evaporation. Many researches showed that the water levels and areas of these alpine lakes presented an increasing tendency (Zhang et al., 2011; Song et al., 2013).

Zhang et al. (2011) analyzed the water level changes of the lakes on the Tibetan Plateau using ICESat altimetry data, and found that $89 \%$ of the saltwater lakes showed an increasing tendency of water level rise with a mean rate of $0.27 \mathrm{~m} / \mathrm{a}$. Based on remote sensing data, this study showed that the rate of increase in the water level of the Sayram Lake was $0.30 \mathrm{~m} / \mathrm{a}$ from 1972 to 2011, which is very similar to that of the saltwater lakes on the Tibetan Plateau. It is suggested that accelerated glacial melting due to global warming is the most likely cause for these recent increases in lake water levels.

\subsection{Further researches on the relationship between glaciers and runoff}

Gao and Jia (2005) estimated the water balance of the Sayram Lake using meteorological data for 1960-2000. Their results showed that the total amount of water entering the lake, total precipitation on the water surface, and total runoff flowing into the lake were all increasing. Over the past several years, both the lake water level and regional precipitation have increased. Using regional climate information and data on the scarce seasonal runoff, Ma et al. (2003) reached the same conclusions. However, there has been very little research on glacial retreat, nor on the relationship between the rate of glacier mass loss and runoff in the Sayram Lake watershed.

Many researches have shown that rates of glacier mass loss in most regions are similar, but a lack of understanding remains regarding the processes involved. This is because climate change cannot directly cause the observed dramatic changes in glacial retreat and increase in runoff (Bolch et al., 2012). Observations of Urumqi Glacier No. 1 in the Tianshan Mountains have revealed remarkable changes of the glacier between 1959 and 2003, indicating strong sensitivity to climate change (Jing et al., 2006). However, there has been a delayed glacier response to climate change, which can take several decades. Therefore, future research on the glacier mass change in the Sayram Lake watershed, including hydrology and runoff in particular, will need to concentrate on analyzing the correlation between glacier variation and climate change.

In this study, the method for estimating the water balance of the entire watershed is simple, and there may be some deviation from actual hydrological processes. Many other factors, especially glacial meltwater, runoff, snowmelt, and permafrost thaw will need to be considered in future research.

\section{Conclusions}

The changes in the Sayram Lake, as well as the glacial retreat, accurately reflect local climate 
change because it is a closed alpine lake almost unaffected by human activities. In other words, these changes are sensitive indicators to climate change. Through comprehensive analyses, this study addressed the changes in the Sayram Lake and the alpine glaciers, and the response of the lake and glacial retreat to climatic fluctuations from 1972 to 2011 . The principal conclusions are as follows. (1) The surface area of the Sayram Lake reached $465.2 \pm 0.2 \mathrm{~km}^{2}$ in 2011 , an increase of $12.0 \pm 0.3 \mathrm{~km}^{2}$ from $453.2 \pm 0.2 \mathrm{~km}^{2}$ in 1972 ; the altitude of the lake water level has increased by $2.8 \mathrm{~m}$ over the past 40 years. (2) Validation using ICESat footprints has shown that ICESat elevation data are very similar to those produced by the hypsometry method, which is well suited to our investigated changes in lake water levels. (3) The area of alpine glaciers has decreased steadily by a total amount of $-2.13 \pm 0.03 \mathrm{~km}^{2}$ from 1972 to 2011 .

As to the Sayram Lake, researches on water supplying and consumption, lake evolution, and response to regional climate change need more field investigation, remote sensing monitoring, and numerical simulation on lake water storage change. Therefore, a long-term research project into the relationship between the variation of lake area and climate change would be enormously beneficial.

\section{Acknowledgements}

This work was financially supported by the National Basic Research Program of China (2015CB954101), the National Science and Technology Basic Special Project (2011FY11040-2), the National Natural Science Foundation of China (41171332, 41571388), and the Surveying and Mapping Geoinformation Nonprofit Specific Project (201512033).

\section{References}

Aizen V B, Aizen E M, Melack J M. 1996. Precipitation, melt and runoff in the northern Tien Shan. Journal of Hydrology, 186(1-4): 229-251.

Aizen V B, Kuzmichenok V A, Surazakov A B, et al. 2007. Glacier changes in the Tien Shan as determined from topographic and remotely sensed data. Global and Planetary Change, 56(3-4): 328-340.

Bai J, Chen X, Li J L, et al. 2011. Changes of inland lake area in arid Central Asia during 1975-2007: a remote-sensing analysis. Journal of Lake Sciences, 23(1): 80-88. (in Chinese)

Bolch T. 2007. Climate change and glacier retreat in northern Tien Shan (Kazakhstan/Kyrgyzstan) using remote sensing data. Global and Planetary Change, 56(1-2): 1-12.

Bolch T, Yao T, Kang S, et al. 2010. A glacier inventory for the western Nyainqentanglha Range and the Nam Co Basin, Tibet, and glacier changes 1976-2009. The Cryosphere, 4(3): 419-433.

Bolch T, Kulkarni A, Kääb A, et al. 2012. The state and fate of Himalayan glaciers. Science, 336(6079): 310-314.

Chai H X, Cheng W M, Zhou C H, et al. 2013. Climate effects on an inland alpine lake in Xinjiang, China over the past 40 years. Journal of Arid Land, 5(2): 188-198.

Ding Y J, Liu S Y, Ye B S, et al. 2006. Climatic implications on variations of lakes in the cold and arid regions of china during the recent 50 years. Journal of Glaciology and Geocryology, 28(5): 623-632. (in Chinese)

Donald O R, Thomas C W. 1997. Dynamics of water-table fluctuations in an upland between two prairie-pothole wetlands in North Dakota. Journal of Hydrology, 191(1-4): 266-289.

Dozier J. 1989. Spectral signature of alpine snow cover from the Landsat Thematic Mapper. Remote Sensing of Environment, 28: 9-22.

Fan Z L, Li J. 1984. Recent changes in the lakes of Xinjiang. Geographical Research, 3(1): 77-86. (in Chinese)

Farr T G, Paul A R, Edward C, et al. 2007. The shuttle radar topography mission. Reviews of Geophysics, 45(2): RG2004, doi: $10.1029 / 2005 R G 000183$.

Gao H Z, Jia Y L. 2005. The evolution characteristics of typical inland lakes in northwest china during the past 40 years and their mechanism. Journal of Arid Land Resources and Environment, 19(5): 93-96. (in Chinese)

González J, Bachmann M, Scheiber R, et al. 2010. Definition of ICESat selection criteria for their use as height references for TanDEM-X. IEEE Transactions on Geoscience and Remote Sensing, 48(6): 2750-2757.

Guo N, Zhang J, Liang Y. 2003. Climate change indicated by the recent change of inland lakes in northwest China. Journal of Glaciology and Geocryology, 25(2): 211-214. (in Chinese)

Hu R J, Ma H, Fan Z L, et al. 2002. The climate trend demonstrated by changes of the lakes in Xinjiang since recent years. 
Journal of Arid Land Resources and Environment, 16(1): 20-27. (in Chinese)

Hu R J, Jiang F Q, Wang Y J, et al. 2007. On the importance of research on the lakes in arid land of China. Arid Zone Research, 24(2): 137-140. (in Chinese)

Jing Z F, Jiao K Q, Yao T D, et al. 2006. Mass balance and recession of Ürümqi glacier No. 1, Tien Shan, China, over the last 45 years. Annals of Glaciology, 43(1): 214-217.

Jones R N, McMahon T A, Bowler J M. 2001. Modelling historical lake levels and recent climate change at three closed lakes, Western Victoria, Australia (c. 1840-1990). Journal of Hydrology, 246(1-4): 159-180.

Kong Y L, Pang Z H. 2012. Evaluating the sensitivity of glacier rivers to climate change based on hydrograph separation of discharge. Journal of Hydrology, 434-435: 121-129.

Kropáček J, Braun A, Kang S C, et al. 2012. Analysis of lake level changes in Nam Co in central Tibet utilizing synergistic satellite altimetry and optical imagery. International Journal of Applied Earth Observation and Geoinformation, 17 : 3-11.

Kutuzov S, Shahgedanova M. 2009. Glacier retreat and climatic variability in the eastern Terskey-Alatoo, inner Tien Shan between the middle of the $19^{\text {th }}$ century and beginning of the $21^{\text {st }}$ century. Global and Planetary Change, 69(1-2): 59-70.

Lanzhou Institute of Glaciology and Cryopedology, Chinese Academy of Sciences. 1986. Glacier Inventory of China III. Tianshan Mountains (Northwestern Junggar Region). Beijing: Science Press, 184. (in Chinese)

Li J L, Fang H, Bao A M, et al. 2011. Spatio-temporal analysis of recent changes of lake area and lake water level at high mountains in Central Asia. Resources Science, 33(10): 1839-1846. (in Chinese)

Li J L, Sheng Y W. 2013. Spatiotemporal pattern and process of inland lake change in the Qinghai-Tibetan plateau during the period of 1976-2009. Arid Zone Research, 30(4): 571-581. (in Chinese)

Liu J S, Wang S Y, Yu S M, et al. 2009. Climate warming and growth of high-elevation inland lakes on the Tibetan Plateau. Global and Planetary Change, 67(3-4): 209-217.

Liu S Y, Yao X J, Guo W Q, et al. 2015. The contemporary glaciers in China based on the second Chinese glacier inventory. Acta Geographica Sinica, 70(1): 3-16. (in Chinese)

Ma D D, Zhang L P, Wang Q J, et al. 2003. Influence of the warm-wet climate on Sailimu Lake. Journal of Glaciology and Geocryology, 25(2): 219-223. (in Chinese)

McFeeters S K. 1996. The use of the normalized difference water index (NDWI) in the delineation of open water features. International Journal of Remote Sensing, 17(7): 1425-1432.

Mercier F, Cazenave A, Maheu C. 2002. Interannual lake level fluctuations (1993-1999) in Africa from Topex/Poseidon: connections with ocean-atmosphere interactions over the Indian Ocean. Global and Planetary Change, 32(2-3): 141-163.

Qin B Q. 1999. A preliminary investigation of lake evolution in 20-century in inland mainland Asia with relation to the global warming. Journal of Lake Sciences, 11(1): 11-19. (in Chinese)

Shi Y F, Zhang X S. 1995. The effect of climate change on surface water resources and future trend in the northwest arid region, China. Science in China (Series B), 25(9): 968-977. (in Chinese)

Shi Y F. 2005. Glacial Inventory of China (Synthesis volume). Shanghai: Science Popularization Press. (in Chinese)

Song C Q, Huang B, Ke L H. 2013. Modeling and analysis of lake water storage changes on the Tibetan Plateau using multi-mission satellite data. Remote Sensing of Environment, 135: 25-35.

Sorg A, Bolch T, Stoffel M, et al. 2012. Climate change impacts on glaciers and runoff in Tien Shan (Central Asia). Nature Climate Change, 2(10): 725-731.

Wang S J. 1978. On relationship between the formation, the evolution of Sayram Lake and the Quaternary glaciation. Arid Land Geography, (1): 47-55. (in Chinese)

Wang S J, Zhang M J, Li Z Q, et al. 2011. Glacier area variation and climate change in the Chinese Tianshan Mountains since 1960. Journal of Geographical Sciences, 21(2): 263-273.

Yao T D, Thompson L, Yang W, et al. 2012. Different glacier status with atmospheric circulations in Tibetan Plateau and surroundings. Nature Climate Change, 2(9): 663-667.

Yao X J, Liu S Y, Li L, et al. 2014. Spatial-temporal characteristics of lake area variations in Hoh Xil region from 1970 to 2011. Journal of Geographical Sciences, 24(4): 689-702.

Zhang G Q, Xie H J, Kang S C, et al. 2011. Monitoring lake level changes on the Tibetan Plateau using ICESat altimetry data (2003-2009). Remote Sensing of Environment, 115(7): 1733-1742. 